\title{
BOVINE TUBERCULOSIS IN RELATION TO HUMAN DISEASE.
}

\author{
By W. G. SAVAGE, \\ M.D., B.Sc.,
}

Medical Officer of Health, and Chief School Medical Officer for the County Council of Somerset; Author of "Milk and the Public Health."

THIS very large question involves the consideration of two separate problems-the amount of human tuberculosis which is of bovine origin, and the prevention of human tuberculosis from bovine sources.

\section{Amount of Human Tuberculosis Infected from Bovine Sources.}

Data is steadily accumulating as to the extent of human infection from bovines, but we are not yet in a position to definitely state the exact

Tabulation of Their Own Cases.

\begin{tabular}{|c|c|c|c|c|c|c|c|c|}
\hline \multirow{2}{*}{ Diagnosis of Cases Examined. } & \multicolumn{2}{|c|}{$\begin{array}{l}\text { Adults I } 6 \text { Years } \\
\text { and over. }\end{array}$} & \multicolumn{2}{|c|}{$\begin{array}{c}\text { Children } \\
5 \text { to } \pm 6 \text { Years. }\end{array}$} & \multicolumn{3}{|c|}{$\begin{array}{l}\text { Children Under } \\
5 \text { Years. }\end{array}$} & \multirow{2}{*}{$\begin{array}{l}\text { Total } \\
\text { Cases. }\end{array}$} \\
\hline & 密 & . & $\underset{\underline{E}}{\stackrel{\dot{E}}{E}}$ & . & 焉 & $\stackrel{\dot{g}}{:}$ & 咅离 & \\
\hline Pulmonary tuberculosis & $27^{8}$ & - & 8 & - & 5 & - & - & $29 I$ \\
\hline $\begin{array}{l}\text { Tuberculosis adenitis (in- } \\
\text { guinal and axillary } \\
\text { Tuberculosis adenitis (cer. }\end{array}$ & I & $\cdots$ & 4 & - & 一 & - & - & 5 \\
\hline vical) $\quad \ldots, \ldots, \ldots$ & 9 & - & I9 & 8 & 6 & I2 & - & 54 \\
\hline $\begin{array}{l}\text { Abdominal tuberctulosis ... } \\
\text { Generalized tuberculosis }\end{array}$ & I & 一 & I & I & - & 3 & 一 & 6 \\
\hline $\begin{array}{l}\text { (alimentary origin) } \\
\text { Generalized tuberculosis } \\
\text { Generalized tuberculosis }\end{array}$ & $r_{2}$ & $\bar{\vdots}$ & $\bar{I}$ & - & $\begin{array}{r}\mathbf{I} \\
\mathbf{I} 2\end{array}$ & $\begin{array}{l}I \\
4\end{array}$ & - & $\begin{array}{r}2 \\
19\end{array}$ \\
\hline (including meninges) ... & 一 & - & - & 一 & 18 & I & $\mathbf{I}^{1}$ & 20 \\
\hline Tubercular meningitis ... & - & - & $\mathrm{I}$ & - & I4 4 & I & 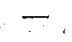 & I6 \\
\hline $\begin{array}{l}\text { Tuberculosis of bones and } \\
\text { joints } \ldots\end{array}$ & . & - & IO & - & 6 & - & 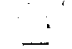 & I7 \\
\hline Geneto-urinary tubercu- & & & & & & & & $I_{1}$ \\
\hline $\begin{array}{llll}\text { losis } & \ldots & \ldots & \ldots\end{array}$ & 3 & $\mathbf{I}$ & I & 一 & 一 & - & $\because$ & \\
\hline Tuberculous abscesses $\ldots$ & I & - & 一 & - & 一 & - & -2 & \\
\hline Totals & $296^{\prime}$ & $I$ & 45 & 9 & 62 & 22 & I & $43^{6}$ \\
\hline
\end{tabular}

percentage from this source. More or less reliable estimates may be arrived at from several points of view of which, in my opinion, the best is that based upon the determination of the types of tubercle bacilli present in human cases. The English Royal Tuberculosis Commission

1 Double infection; both types isolated ; child thirteen months old; the mesenteric nodes gave human type; meningeal fluid gave bovine type. 
investigated 108 cases of human tuberculosis other than lupus, but the most extensive records are contained in the very important paper of Park and Krumwiede ${ }^{1}$ and their assistants. These investigators determined the type of tubercle bacillus present in tuberculous material sent to them from different institutions and from a variety of sources, and examined regardless of the type of infection. The tubercle bacilli

\section{Combined Tabulation, Cases Reported Including Their Own Series of Cases.}

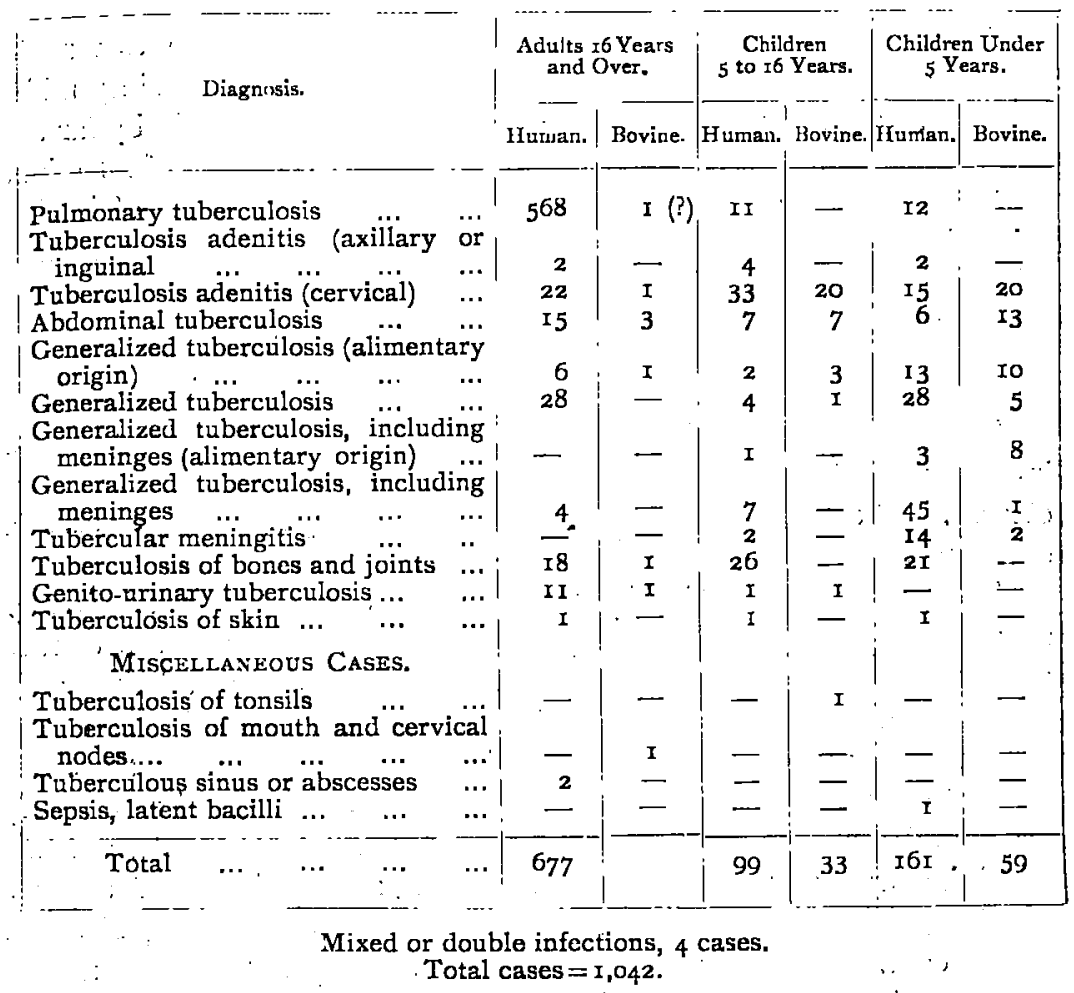

were all, in the first place, isolated by guinea-pig inoculation. In addition, they also tabulated the results of their own and seventeen other groups of investigators into one combined table. Their own results and the combined results are shown in the two previous tables.

This table shows that the bovine type of bacillus was only found - in r.3 per cent. of the adults, but in 25 per cent. of the children five to sixteen years, and in 26.7 per, cent. of the children under five years of

1 Park and Krumwiede : " Studies from the Research Laboratory, Department of Health, New York City," vol. v, Igro. 


\section{I7O THE BRITISH JOURNAL OF TUBERCULOSIS}

age. When the phthisis cases are excluded, the adult percentage rises to $7 \cdot 3$.

These investigations show that while pulmonary tuberculosis is almost invariably of human origin, a considerable proportion of the cases of other varieties of tuberculosis, especially glandular and intes. tinal affections in children, are infected with bacilli of bovine type, and derived from bovine sources. Whatever the exact proportion, it cannot be regarded as other than a serious menace to health.

Prevention of Human Infection from Bovine Sources.

Apart from exceptional circumstances, bovine infection to man is spread entirely from tuberculous meat and milk, including milkproducts. Of these milk, and to a lesser extent butter, is by far the most important, and must be regarded as the main vehicle of infection.

The problem of the prevention of human tuberculosis of bovine origin involves two quite separate considerations: (I) The control and elimination of bovine tuberculosis ; (2) the prevention of human infection from material containing bovine tubercle bacilli.

\section{The Control and Elimination of Bovine Tuberculosis.}

The control of bovine tuberculosis is urgently required in the interest of agriculture, and quite apart from its relationship to human disease. The loss to the agricultural community from this disease is enormous.

The eradication of this disease amongst cows and oxen is admittedly an extremely difficult task, owing to the insidious nature of the disease and its extremely wide prevalence. The suggestion that all the cattle in the country should be tested with tuberculin, and all found tuberculous killed and compensation paid, is wholly impracticable since the amount of compensation required would be enormous, while no surety that the disease was extirpated could be arrived at, unless the animals surviving were all re-tested with tuberculin, and all imported animals regularly tested and re-tested. Apart from this, the killing of about 25 per cent. of all the milch cows in the country would cause a milk famine. All responsible veterinary authorities are united in advocating that measures for dealing with this disease must be on selective and preventive lines, operating somewhat slowly.

The best known method for the eradication of this disease is that of Bang, of Denmark. Delépine has advanced a modification of this method. In his method great importance is attached to the work of eradication not being confined to individual farms, or small groups of farms, scattered among other farms where tuberculosis is left entirely or partly unchecked. The principle of both these methods is the separation of the healthy from the diseased animals, and the rearing of a healthy non-infected stock. 
Ostertag's method is based upon the elimination of all cases of "open tuberculosis" from dairy herds. Vaccination of cattle against tuberculosis has also been advocated and practised, but in actual practice it has not given satisfăctory results. Space will not permit a full description of these methods. ${ }^{1}$

\section{The Prevention of Human Infection from Material Containing Bovine Tubercle Bacilli.}

The eradication of bovine tuberculosis is a long and difficult matter, and many authorities have taken definite action to try and prevent tubercle-infected milk from reaching the inhabitants under their control. For this purpose special legal powers have to be acquired.

Such powers were first obtained by Manchester, and they are usually known as the Manchester Model Milk Clauses.

These special powers have been in force in Manchester since Igoo,

Tubercle Bacilli in Mixed Milk Samples (Percentages).

\begin{tabular}{|c|c|c|c|c|c|c|c|c|c|c|}
\hline & Igor. & IgO2. & Ig03. & I904: & I905. & I906. & 1907. & I908. & T909. & I910. \\
\hline $\begin{array}{lll}\text { Manchester }^{2} & \ldots & \ldots\end{array}$ & $8 \cdot 7$ & $8 \cdot 57$ & $10 \% 42$ & 6.7 & $6 \cdot 15$ & $6 \cdot 2$ & $5 \times 74$ & $8 \cdot 28$ & $5 \cdot 14$ & - \\
\hline $\begin{array}{c}\text { Liverpool, } \\
\text { samples }^{3}\end{array}$ & $6 \cdot I$ & $7 \cdot 3$ & $5^{\circ} I$ & $9^{2} 2$ & $3 \cdot 8$ & 6.8 & 47 & $3 \cdot 3$ & $I \cdot 8$ & 4.1 \\
\hline $\begin{array}{l}\text { Liverpool, town samples } \\
\text { Sheffield, country }\end{array}$ & 0.6 & 0.4 & 0.8 & $I \cdot 5$ & 0.4 & $1 \cdot 4$ & $I \cdot 5$ & $2 \cdot 0$ & - & I. 4 \\
\hline samplest & - & $177^{* 8}$ & $16 \cdot 7$ & $6 \cdot 7$ & $\mathrm{I}_{4} 7$ & $9^{\circ} 6$ & $9^{\circ} 7$ & 9.9 & I0*9 & $10 \% 4$ \\
\hline $\begin{array}{c}\text { Birmingham, } \\
\text { samples }{ }^{5}\end{array}$ & & Pri & to 1 & $908=$ & $I_{4}$ per & cen & & $11 \cdot 3$ & $7 \cdot 5$ & $7 \cdot 3$ \\
\hline Leeds, country samples ${ }^{6}$ & - & - & - & - & 一 & - & -- & $25 \cdot 3$ & $16 \%$ & $\overline{5.6}$ \\
\hline $\begin{array}{lll}\text { Sunderland } & \ldots & \ldots\end{array}$ & 一 & 一 & 一 & - & - & - & 25 & $\begin{array}{l}77^{\circ} \\
1 I^{\circ} 6\end{array}$ & $\begin{array}{r}7 \% 4 \\
10.4\end{array}$ & $3 \cdot 6$ \\
\hline London (L.C.C. $)^{8}$ & - & - & - & - & - & - & & & & \\
\hline
\end{tabular}

and in other cities for considerable periods, so that it is possible to obtain an estimate as to how far they have succeeded in attaining the objects for which they were framed. These milk clauses require notification by dairymen of all cases of udder tuberculosis among cows in cowsheds sending milk into the city, and prohibit the sale of milk from such cows within the city. They give powers for collecting milk samples and additional powers of inspection for cowsheds within the city. Their essential and characteristic feature is, however, the power of inspection which they give of cowsheds and cows supplying milk into

1 For a fairly complete description see the writer's book, " Milk and the Public Health." London: Macmillan and Co. Igr2.

2 Kindly supplied to me by Dr. Niven, Medical Officer of Health.

3 Medical Officer of Health Report, IgIo.

4 Ibid.

5 Kindly supplied to me by Dr. Robinson, Medical Officer of Health.

6 Medical Officer of Health Reports, I908, 1909.

7 Kindly supplied to me by Dr. Renney, Medical Officer of Health.

8 Medical Officer of Health, London County Council's Annual Reports, Igo8, I 909 . 


\section{I72 THE BRITISH JOURNAL OF TUBERCULOSIS}

the city, although themselves outside, whenever the city authorities suspect milk from such farms to be tuberculous. The inspection can be followed up by prohibiting the infected milk from being supplied within the city as long as it is dangerous. The effectiveness of these powers may be considered from two points of view :

(a) Their Influence upon the Prevalence of Tubercle Bacilli in the Milk Supplied to the City Enforcing Them.-The table on p. $\mathrm{I} 7 \mathrm{I}$ shows some of the results obtained in certain cities.

The Manchester figures are the most important, as they deal with a very large number of samples, extending over a series of years.

The table shows that there has been some diminution in the percentage of tuberculous samples, but that apart from the first few years of working, it has not been continuous or very marked. During the first few years some of the worst offenders would doubtless be weeded out and warned off from supplying the particular city. The amount of tuberculous milk for Manchester drops to about 6 per cent., and to about 9 per cent. for Sheffield, and there it remains. No regular, consistent diminution in the infective quality of the milk is observable.

(b) Their Influence upon the Prevalence of Udder Tuberculosis.-The following table supplies some data:

\begin{tabular}{|c|c|c|c|c|c|c|}
\hline \multirow[b]{2}{*}{. } & \multirow[b]{2}{*}{ Year. } & & \multicolumn{2}{|c|}{ Manchester. ${ }^{\mathbf{I}}$} & \multicolumn{2}{|c|}{ Sheffield. ${ }^{2}$} \\
\hline & & & $\begin{array}{l}\text { Percentage of } \\
\text { Farmers } \\
\text { Sending Tuber- } \\
\text { culous Milk. }\end{array}$ & $\begin{array}{l}\text { Percentage of Out- } \\
\text { side Cows Found } \\
\text { with Udder } \\
\text { Tuberctlosis. }\end{array}$ & $\begin{array}{l}\text { Percentage of } \\
\text { Country Cows } \\
\text { with Udder } \\
\text { Tuberculosis. }\end{array}$ & $\begin{array}{c}\text { Percentage of } \\
\text { City Cows } \\
\text { with Udder } \\
\text { Tuberculosis. }\end{array}$ \\
\hline IgOr & & & & $I_{4}$ & $\ldots$ & \\
\hline IgO2 & $\ldots$ & $\ldots$ & 10.4 & 2.5 & $2 \%$ & $\begin{array}{l}0.47 \\
0.31\end{array}$ \\
\hline 1903 & $\ldots$ & $\ldots$ & 13.6 & $I \cdot I$ & 0.96 & 0.45 \\
\hline 1904 & $\ldots$ & $\ldots$ & $9: \mathbf{I}$ & 0.6 & 0.59 & 0.45 \\
\hline 1905 & $\ldots$ & $\ldots$ & $8 \cdot 3$ & 0.9 & 309 & 0.26 \\
\hline I & $\ldots$ & $\ldots$ & $7 \%$ & $I=5$ & $3^{-6}$ & 0.14 \\
\hline 1907 & $\ldots$ & $\ldots$ & $6 \cdot 76$ & $I \cdot I$ & $I \cdot 9^{\prime}$ & 0.8 \\
\hline 1908 & $\ldots$ & $\ldots$ & $9 \cdot 34$ & 0.9 & 24 & 0.9 \\
\hline 1909 & $\cdots$ & $\ldots$ & 5.79 & $\mathrm{I}^{\circ} \mathrm{O} 3$ & $4^{\circ} \circ$ & $\mathrm{I} \cdot \mathrm{I}$ \\
\hline Avera & ge ... & .*. & $8 \cdot 6$ & - & $2 \cdot 3$ & - \\
\hline
\end{tabular}

These tables show that the percentage of farmers sending tuberculous milk to Manchester varied from 5.79 to $13 \cdot 6$, the average being $8 \cdot 6$. Except for 1908 , there has been a steady, though not very marked, decline since I903. In other words, there has probably been a moderate but steady diminution in the number of farms with cows suffering from open tuberculosis sending millk to Manchester.

As regards udder tuberculosis, the table shows no percentage

1 From information kindly furnished by Dr. Niven.

Report of Medical Officer of Health (Dr. Scurfield), Sheffield, rgog. 
diminution in either Manchester or Sheffield. In Sheffield during rgog, the veterinary inspectors found as many as forty-two cows with tuberculosis of the udder, out of about 3,600 cows stalled in Sheffield City.

Judged from these two points of view, these special powers have (apart from their initial effects) only attained a moderate measure of success, as regards their effectiveness to protect the community obtaining them against the dangers of bovine tuberculosis spread by milk.

Several considerations, apart from actual results achieved, show that markedly beneficial results of a permanent character are not likely to accrue. Thus a consideration of the powers given, and the clauses themselves, show that they are essentially based upon an assumption which cannot be accepted without large reservations. The assumption is that the presence of tubercle bacilli in milk is due to the herd supplying the milk containing one or more cows affected with clinically recognizable udder tuberculosis, and if these cows are removed the danger ceases.

This assumption, in view of the findings of the Royal Commission on Tuberculosis, and of other investigators, cannot be accepted as tru In further support of this statement may be instanced the fact that in a considerable number of cases in which tubercle bacilli are found in milk, no cases of udder tuberculosis, which can be diagnosed, are found. Apparently the cow-keeper in such cases may continue to send unchecked his milk into the city.

Again, action along the lines of the milk clauses must fail to effectively deal with the whole problem, since they attempt to treat a symptom; they do not treat the underlying condition, bovine tuberculosis. Applied to special areas only, as already mentioned, they exert a practically negligible influence upon the manufacture of bovine tuberculosis (although they may divert its products to unprotected places) but merely deal with the small amount of it which comes under their special cognizance. If the clauses were universally applied they would no doubt be made much more effective, but even then the powers given are insufficient.

One of the greatest weaknesses of the clauses is the absence of powers to deal with a cow with udder tuberculosis when found. She is difficult to diagnose and a potent danger to mankind, and yet when the elaborate business of bacteriological examination and veterinary inspection reaches its fruition and a cow with a tuberculous udder is found, all the law mildly enacts is :

I. The cow owner must not keep or permit such cow to be kept in any field, shed, or other premises along with other cows in milk under a penalty.

1 The italics are mine: Apparently she may be kept with calves or cows now dry which will soon again be in milk. 


\section{I74 THE BRITISH JOURNAL OF TUBERCULOSIS}

2. The milk of such a cow shall not be mixed with other food, and shall not be sold or used for human food, and shall not be sold or used for food of swine, or other animal, unless and until it has been boiled.

In other words, the owner can banish the cow from other cows in milk and stop using her milk, and then he has fulfilled the whole of the law. There is apparently nothing to prevent him selling the cow. with or without saying anything about the udder condition.

It is well-known that the powers granted are less than those originally asked for, and the slaughter of cows suffering from udder tuberculosis was one of the clauses which Parliament failed to endorse.

\section{Practical Procedures.}

In my opinion, while immediate action is required to deal with existing conditions, and to prevent tubercle bacilli being shed into milk from cows with tuberculous udders or clinically diagnosable tuberculosis, the real lines of prevention are to help and encourage the farmer and breeder to eradicate tuberculosis from their herds. The former is a necessary measure, but it is only a palliative.,

There is no doubt that the community for its own interest and protection will have to financially assist the farmers in the fight against bovine tuberculosis. The present policy of inactivity, or of localized efforts to diminish tubercle bacilli in milk, can never do permanent good, and money can be better employed in other directions. There appears to be a good deal of difference of opinion as to the directions in which financial assistance should be given. In Denmark compensation is paid for cows slaughtered suffering from udder tuberculosis. I believe this is not a good investment for the community. We must aim at making it an economic necessity for the farmer to get rid of insanitary cowsheds and other conditions which breed tuberculosis.

All animals suffering from udder or advanced tuberculosis should certainly be slaughtered. It might be reasonable, and probably would be politic, if any general scheme of prevention is inaugurated, to.pay compensation for such animals for perhaps the first two or three years, but after that, if any cows with advanced tuberculosis are found in cowsheds, the owners should be fined. Any compensation should be paid out of Imperial rather than local funds, otherwise the urban districts do not pay their share. All cows excreting tubercle bacilli, if not killed, should be branded so that they may never be used for milk production.

To find out such animals, an adequate staff of veterinary inspectors must be provided, while bacteriological facilities will have to be much more extensively employed. Assistance to farmers and breeders should 
be in the direction of the free supply of tuberculin and the free services of veterinary surgeons. The public must also be educated so that they will be willing to pay more for milk guaranteed free from tubercle bacilli than for ordinary market milk.

It would be a decided advantage if at least a few farms supplying milk from non-tuberculous cows could be obtained for each large urban area such as they are doing in Birmingham. 